\title{
"Impact of tax fairness and tax knowledge on tax compliance behavior of listed manufacturing companies in Nigeria"
}

\begin{tabular}{|c|c|}
\hline AUTHORS & $\begin{array}{l}\text { Olufemi Oladipo (D) } \\
\text { R } \\
\text { Tony Nwanji (D) } \\
\text { Damilola Eluyela (D) } \\
\text { R } \\
\text { Bitrus Godo } \\
\text { Adekunle Adegboyegun }\end{array}$ \\
\hline ARTICLE INFO & $\begin{array}{l}\text { Olufemi Oladipo, Tony Nwanji, Damilola Eluyela, Bitrus Godo and Adekunle } \\
\text { Adegboyegun (2022). Impact of tax fairness and tax knowledge on tax } \\
\text { compliance behavior of listed manufacturing companies in Nigeria. Problems } \\
\text { and Perspectives in Management, 20(1), 41-48. doi:10.21511/ppm.20(1).2022.04 }\end{array}$ \\
\hline DOI & http://dx.doi.org/10.21511/ppm.20(1).2022.04 \\
\hline RELEASED ON & Tuesday, 11 January 2022 \\
\hline RECEIVED ON & Tuesday, 01 December 2020 \\
\hline ACCEPTED ON & Tuesday, 13 July 2021 \\
\hline LICENSE & $\begin{array}{l}(c)) E Y \\
\text { This work is licensed under a Creative Commons Attribution } 4.0 \text { International } \\
\text { License }\end{array}$ \\
\hline JOURNAL & "Problems and Perspectives in Management" \\
\hline ISSN PRINT & $1727-7051$ \\
\hline ISSN ONLINE & $1810-5467$ \\
\hline PUBLISHER & LLC "Consulting Publishing Company "Business Perspectives" \\
\hline FOUNDER & LLC "Consulting Publishing Company "Business Perspectives" \\
\hline
\end{tabular}

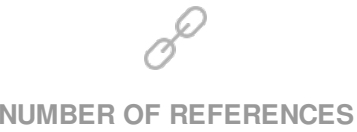

30
NUMBER OF FIGURES

0
NUMBER OF TABLES

5

(C) The author(s) 2022. This publication is an open access article. 


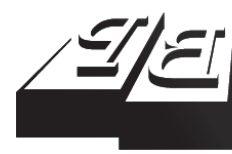

BUSINESS PERSPECTIVES

(2)

LLC "CPC "Business Perspectives" Hryhorii Skovoroda lane, 10, Sumy, 40022, Ukraine www.businessperspectives.org

Received on: $1^{\text {st }}$ of December, 2020 Accepted on: $13^{\text {th }}$ of July, 2021 Published on: $11^{\text {th }}$ of January, 2022

(๑) Olufemi Oladipo, Tony Nwanji Damilola Eluyela, Bitrus Godo Adekunle Adegboyegun, 2022

Olufemi Oladipo, Ph.D. in Accounting, Lecturer, Landmark University Sustainable Development Goal 4 (Quality Education) Research Group, Department of Accounting and

Finance, College of Business and Social Sciences, Landmark University, Nigeria. (Corresponding author)

Tony Nwanji, Ph.D. in Accounting, Associate Professor, Department of Accounting and Finance, College of Business and Social Sciences, Landmark University, Nigeria.

Damilola Eluyela, M.Sc. in Accounting, Lecturer, Department of Accounting and Finance, College of Business and Social Sciences, Landmark University, Nigeria.

Bitrus Godo, M.Sc. in Accounting, Lecturer, Department of Accounting, Federal Polytechnic, Nigeria.

Adekunle Adegboyegun, M.Sc. in Accounting, Lecturer, Department of Accounting, Adekunle Ajasin University, Nigeria.
Olufemi Oladipo (Nigeria), Tony Nwanji (Nigeria), Damilola Eluyela (Nigeria), Bitrus Godo (Nigeria), Adekunle Adegboyegun (Nigeria)

IMPACT OF TAX FAIRNESS AND TAX KNOWLEDGE ON TAX COMPLIANCE BEHAVIOR OF LISTED MANUFACTURING COMPANIES IN NIGERIA

\begin{abstract}
Tax compliance is a major contemporary debate surrounding corporate taxation in the business world. The tax avoidance issue, which remains an ethical problem for companies, has been a general concern in developed and developing countries alike. The main problem of this study is a non-tax compliance behavior of the corporate organization taxpayers in Nigeria. This study examined the influence of tax fairness on the tax compliance behavior of listed manufacturing companies in Nigeria. The paper adopted a survey research method, and four hundred (400) copies of the questionnaire were administered to the selected manufacturing companies of both consumer and industrial goods sectors. The Laffer Curve Theory underpinned this study and Correlation Analysis, Analysis of Variance (ANOVA), and Multiple Regression Analysis were also employed. The study found that there is a significant level of tax compliance among the listed manufacturing companies in Nigeria. The study also shows that the corporate taxpayer's perception of fairness of $-2.765(0.006)$ has a significant impact on corporate taxpayers' willingness to pay taxes and tax knowledge of $4.601(0.000) \mathrm{sig}$ nificantly influenced tax compliance. Based on tax knowledge, the study recommends that tax authorities must improve the knowledge of taxpayers and tax collection agents through programs, initiatives, and training on tax awareness.
\end{abstract}

Keywords

taxation, tax fairness, tax knowledge, manufacturing company, Nigeria

JEL Classification $\quad \mathrm{H} 21, \mathrm{H} 30$

\section{INTRODUCTION}

The Nigerian economy is the largest in Africa with a Gross Domestic Product (GDP) of 375.8 billion US dollars in the year 2017, while South Africa's GDP of 349.4 billion US dollars trails behind Nigeria. The Nigerian economy is made up of many sectors with a total market capitalization of N22.35 trillion ( $\$ 61.44$ billion) as at September 2018 , of which the manufacturing sector is one of them (Nigerian Stock Exchange, 2018). The manufacturing industry applies to those sectors and operations that are active in the transformation, production, and processing of items that create value addition to the commodity (Falade \& Olagbaju, 2015). The activities in the manufacturing sector cover a wide range of products, and it contains manufacturing, metal/ plastic, ICT/electrical, garment and clothes, accessories, concrete, and infrastructure. Currently, other manufacturing activities have been divided into eleven different activities, where food, beverages, and tobacco are the dominant activities of the sector.

Due to the size and nature of the manufacturing sector, it is expected that a more substantial portion of the Nigerian tax revenue will be de- 
rived from this sector by the government and will be used to finance its activities to enhance economic growth and development in the country. Despite the contribution of the manufacturing sector to the tax revenue generated in the country, the level of tax compliance of this sector is not specified.

Taxation is the most unstable and sophisticated issue in governance both in evolving and technologically advanced countries. Akintoye and Tashie (2013) noted that tax proceeds are vital mechanisms for economic expansion in many developing countries, such as Nigeria, as tax-generated taxes help the economy to provide facilities and social welfare support.

Tax compliance can be regarded as the ability of tax-paying citizens to pay their taxes. In contrast, nontax obedience is a failing on the part of tax-paying citizens to meet their tax obligation intentionally (Kirchler, 2007). The tax compliance determinant factors can be viewed from different perspectives: socio-psychological factor, which deals with attitudes, norms, fairness, tax knowledge and their relationship with tax compliance; political factor deals with the complexity in the tax law; and economic factor deals with the effect on tax enforcement behavior, with audit thresholds, fines, tax rates, and income.

The main problem of this study is a non-tax compliance behavior, which is an issue throughout the world and may have unfriendly outcomes on the economy (Lipatov, 2012). Non-tax compliance behavior, however, is an issue that affects tax growth and development as one of the primary revenue sources of government in the country. Oluyombo and Olayinka (2018) identified different factors that contributed to non-compliance behavior: misappropriation of tax collected, corruption, weak tax administration, political instability, heavy tax burden, and multiplicity of taxes. Nigeria's tax compliance rate is significantly low, 10 percent compared to other countries based on the Federal Inland Revenue Service figures (FIRS, 2018). However, in the United States of America, internal revenue service estimated that 100 billion dollars were lost yearly to tax non-compliance (Bobek \& Hatfield, 2003).

Therefore, this study addressed the issue of non-tax compliance, which has been a general problem surrounding corporate taxation in the business world.

\section{LITERATURE REVIEW}

The issue of tax revenue has been regarded as an encumbrance that individual and corporate organizations must contribute to sustaining the developmental projects of the government. It is an economic policy device that the state deploys to attain its macroeconomic goals and objectives. The principal economic goals of any evolving nation are to ensure that adequate revenue is generated to enhance the quality of human life in the country (Afuberoh \& Okoye, 2014). Oladipo et al. (2019) viewed the vital aspect of tax compliance and found that it will improve government revenue generation positively when individual taxpayer sees the tax system and policy as fair, trustworthy, just, and judicious spending of the tax revenue.

Tax administration is the process in which relevant tax authority applies tax laws and, in general, the practical interpretation of laws. According to
Afuberoh and Okoye (2014), the government programs and adequacy of the tax policy is the primary concern of the tax system in any country while tax administration is to guarantee the proper application of relevant tax laws and also ensure that all the revenue generated are paid directly into the government account. In achieving anticipated objectives, sound policies, rules, and regulations must be put in place, and it is also crucial to entirely execute these policies, rules, and regulations judiciously. In Nigeria, the administrative organ of the tax authority is responsible for the implementation of tax policies.

Tax fairness has been recognized as one of the attributes of a sound tax system (Wrede, 2014), and it plays a vital role in determining a tax compliance behavior of taxpayers. The influence of tax fairness on taxpayers' compliance behavior has gained extensive debate by Marion and Muehlegger (2018), Khasawneh et al. (2008), and Wrede (2014). Most 
of these studies perceive taxpayers to comply with a tax system that is considered fair. However, there are various dimensions of tax fairness which include horizontal fairness (Faizal \& Palil, 2015), vertical fairness (Gberegbe et al., 2015), administrative fairness (Nagel et al., 2019), personal fairness (Bayer \& Cowell, 2016), and general fairness (Zandi, 2016).

Horizontal fairness is when taxpayers with equal socioeconomic backgrounds pay the same tax rate. Vertical fairness implies that payments should be made by people of different economic conditions at different levels. Administrative fairness refers to the contents of tax laws and procedures that tax authorities employ. Personal fairness often relates to the impression by taxpayers of whether the tax system is fair. Lastly, retributive fairness is concerned about how non-compliant taxpayers are sanctioned and punished. In this study, tax fairness is considered from the aspect of general fairness. This aspect measures an individual judgment on whether or not a country's tax system is fair.

Gberegbe et al. (2015) also studied the perception of tax fairness on personal income tax compliance in Nigeria, and the result shows that a positively significant relationship exists between tax fairness perception and personal income tax compliance in River States, Nigeria. However, Zandi (2016) viewed the relationship between tax fairness and tax compliance from the aspect of rewards. It was noted that the tax authority should establish various reward systems to compensate taxpayers that are compliant with tax requirements. It was concluded that these taxpayers would view the tax system as a fair one and thus tax compliance will increase.

This study considers tax knowledge to represent tax education, which is similar in meaning. The degree of tax awareness and details is an important element in how taxpayers pay taxes. Tax knowledge was recognized as one of the critical elements influencing the conduct of tax compliance behavior (Newman et al., 2019; Olaoye et al., 2017). Saad (2014) concluded that tax knowledge can be divided into two aspects, namely, knowledge through formal education and knowledge directed at possible opportunities to evade tax. In the first aspect, the level of formal education received by taxpayers on tax matters is a crucial factor that contributes to tax compliance behavior.
According to Newman et al. (2019), taxpayers with adequate formal education and knowledge are expected to have adequate information about tax and fiscal policies due to their level of education and exposure. It was found that tax knowledge is an important factor in determining tax compliance behavior. Pratama (2018) found that when taxpayers possess higher tax awareness, they follow high ethical behaviors. Knowledge of tax and fiscal policies was viewed to be an essential factor when determining the level of taxpayers' compliance behavior. In addition, Bernard et al. (2018) assessed the impact of tax understanding and knowledge on tax compliance among shareholders in export production areas in Kenya. The study shows that tax knowledge and awareness have a positive relationship with taxpayers' ability to understand tax laws and thus increase tax compliance. In summary, tax knowledge has an enormous impact on tax compliance behavior.

Faizal et al. (2017) examined the correlation between justices, trust, and tax compliance behavior in Malaysia. The findings revealed that justice and trust have a significant effect in determining tax compliance behavior in Malaysia. Sausgruber and Tyran (2014) noted that when the tax authority treats taxpayers nicely and fairly, they would cooperate and be more motivated to comply with the requirement of the tax system enacted by the tax authority. Jurney et al. (2017) argued that taxpayers should believe in a government that any tax levy against the citizens is fair and equitable as much as possible.

Doran (2009) investigated the relationship between the knowledge-ability of taxpayers and tax compliance behavior; the relationship was found to be significant. In Nigeria, Oladipupo and Obazee (2016) used ordinary least square (OLS) regression to measure the influence of taxpayers' knowledge and the tax penalty on tax compliance among SMEs. This study is in line with Olaoye et al. (2017) who stated that tax knowledge has a significant positive impact on tax compliance.

\section{AIM AND HYPOTHESES}

This study aims to examine the influence of tax fairness and tax knowledge on the tax compliance behavior of listed manufacturing companies in Nigeria. 
Based on the aim of this study, the relevant null hypotheses were formulated:

Ho: There is no significant relationship between tax fairness and tax compliance among listed Nigerian manufacturing companies.

$\mathrm{Ho}_{2}$ : There is no significant relationship between tax knowledge and tax compliance among listed manufacturing companies in Nigeria.

\section{METHODS}

The study uses the Laffer Curve Theory for the analysis. According to this theory, the idea was advocated that reducing tax rates would result in higher revenue, which promotes and enhances economic growth. It shows the relationship between tax rates and government revenue. According to Afuberoh and Okoye (2014), this theory is illustrated with a graphical curve (Laffer Curve, which is constructed through experiments).

The Laffer Curve indicates the relationship between tax rates and government revenue. It suggests that at the moment when there is an increase in the tax rates, definitely, government revenue will also increase. Based on the graph, the government will like to be at a tax rate of $100 \%$, which will generate more revenue to the detriment of the workers, and the people will be reluctant to work at that point because all their earning will be going into the government purse. The optimal point is at $\mathrm{T}^{\star}$ where the government will generate more revenue, and the workers (taxpayers) will continue to work effectively and efficiently, which will enhance economic growth.

This study adopted a survey research method (questionnaire) (Appendix A) and all listed manufacturing companies that are in both the industrial and consumer goods segment of the economy, other than companies that carried out petroleum operations, were the population of this study. The sample size for this study was 20 listed manufacturing companies out of 35 listed companies in both consumer and industrial goods sectors. Given the unequal number of companies in these two sectors, the study selected ten (10) listed companies each from the two sectors, which will give room for equal representation from the two sectors.

The totality of the questionnaire used for the analysis of this study was 278 out of 400 copies of the questionnaire distributed to the respondents (tax managers, accountants, auditors, and corporate responsibility staff). The model used to examine tax compliance, tax fairness, and tax education of listed Nigerian manufacturing companies by:

$$
\text { TComplB }=f(\text { TFarn, TEdu }),
$$

where TComplB is the tax compliance behavior, TFarn is tax fairness, TEdu is tax knowledge.

Hence, the explicit form of the model is calculated by:

TComplB ${ }_{t}=\beta_{0}+\beta_{1}$ TFarn $+\beta_{2}$ TEdu $+\mu_{t}$,

where $\beta_{0}$ is the intercept or the constant term, $\beta_{1}$, and $\beta_{2}$, are the parameters for the independent variables, tax fairness (TFarn), tax knowledge $(T E d u)$, respectively. The subscript ' $t$ ', is the period of observation while $\mu_{t}$ is the stochastic error term.

\section{RESULTS}

Based on the methodology adopted to collect the data, the study used regression analysis to examine the impact of tax fairness and tax education on the tax compliance behavior of listed manufacturing companies in Nigeria. A reliability test was conducted using Cronbach's alpha. The reliability coefficient was found to be 0.73 . Since the benchmark for reliability coefficient is $0.67-0.7$, the above reliability coefficient indicates significant internal consistency of the items in the research instrument (questionnaire), thus indicating that the instrument is reliable.

The regression results are shown in Table 2.

Table 2 depicts the model summary of tax compliance and ethical tax behavior of the sampled firms 
Table 1. Reliability statistics

Source: Authors' computation using IBM SPSS.

\begin{tabular}{|c|c|}
\hline Cronbach's alpha & No. of Items \\
\hline 0.726 & 30 \\
\hline Part 1. Value & 0.630 \\
\hline No. of Items & $15^{a}$ \\
\hline Part 2. Value & 0.552 \\
\hline No. of Items & $15^{\mathrm{b}}$ \\
\hline Total No. of Items & 30 \\
\hline Correlation Between Forms & 0.500 \\
\hline Spearman-Brown Equal Length & 0.666 \\
\hline Unequal Length & 0.666 \\
\hline Guttman Split-Half Coefficient & 0.666 \\
\hline
\end{tabular}

Note: a - Predictors: (Constant), Avg. Tax Fairness, and Avg. Tax Education. b - Dependent Variable: Avg. Tax Compliance.

Table 2. Model summary

\begin{tabular}{c|c|c|c|c:c}
\hline Model & $\mathbf{R}$ & $\boldsymbol{R}$ Square & Adjusted $\boldsymbol{R}$ Square & Std. Error of the Estimate & Durbin-Watson \\
\hline 1. & $0.340^{\mathrm{a}}$ & 0.116 & 0.103 & 0.26569 & 2.244 \\
\hline
\end{tabular}

Table 3. Coefficients of independent variables

\begin{tabular}{|c|c|c|c|c|c|}
\hline \multirow{2}{*}{ Model } & \multicolumn{2}{|c|}{ Unstandardized Coefficients } & \multirow{2}{*}{$\begin{array}{c}\text { Standardized Coefficient } \\
\text { Beta } \\
\end{array}$} & \multirow{2}{*}{$t$} & \multirow{2}{*}{ Sig. } \\
\hline & B & Std. Error & & & \\
\hline (Constant) & 2.979 & 0.315 & & 9.461 & 0.000 \\
\hline Avg. Tax Fairness & -0.163 & 0.059 & -0.159 & -2.765 & 0.006 \\
\hline Avg. Tax Knowledge & 0.222 & 0.048 & 0.0267 & 4.601 & 0.000 \\
\hline
\end{tabular}

Note: a - Dependent Variable: Avg. Tax Compliance.

under study. The summary reflects an $R$-square of 0.116 , which approximately stands at $12 \%$, implying the variation amidst the constructs. It further buttresses that the tax compliance behavior of the sampled firms can be explained by the independent constructs (tax fairness and tax education). In contrast, the remaining $88 \%$ are other factors were not captured by this model, which are outside the model of this study. Furthermore, the computed value of the Durbin-Watson statistic is 2.244. This value lies between DU, 4 - DU, thus indicating that the stochastic error terms are not serially correlated.

$$
\text { TCompl } \beta_{t}=\beta_{0}+\beta_{1} \text { TFarn }+\beta_{2} \text { TEdu }+\mu_{t} \text {, }
$$

Tax Compliance Behavior $=2.979-0.163$ Tax fairness +0.222 Tax knowledge.

The $t$ value and the significance level are as follows:

t/sig. $=9.461(0.000),-2.765(0.006)$, and 4.601 (0.000), for constant, tax fairness, and tax knowledge. This implies that both tax fairness and tax knowledge are significant variables for the tax compliance behavior of taxpayers.

\section{DISCUSSION}

Discussing $\mathrm{Ho}_{1}$, there is no significant relationship between tax fairness and tax compliance behavior of listed manufacturing companies in Nigeria. Findings from Table 3 do not align with the null hypothesis, the interaction is statistically significant, as demonstrated by the $t$-stats and p-value of -2.765 and 0.006 respectively. The result depicts that tax fairness has a negative and significant of about -0.159 influence on tax compliance behavior. This shows that the Nigerian tax system does not reflect administrative feasibility in the area of convenience, justness, and effectiveness. The result aligns with Guzel et al. (2019) who found a positive relationship between tax compliance and justice.

Considering $\mathrm{Ho}_{2}$, there is no significant relationship between tax knowledge and tax compliance among listed manufacturing companies in Nigeria. The result from Table 3 depicts a deviation from the null hypothesis. This result is noticeable by the $t$-stats and $p$-value (4.601 and 0.000$)$ concurrently. The outcome reveals that tax knowl- 
edge has a positive and significant association with tax compliance, and the degree of association stands at 0.0026 , inferring that a slight increase in the awareness of tax individuals would have about 0.0026 effects on the tax compliance behavior of the sampled firms under study.

This implies that the provision of adequate tax education to taxpayers and increased advertising of incentives for voluntary compliance will enhance tax revenue generation to the government. Training of government tax agents also will enhance tax compliance behavior. Tax training would lead to an increase in tax compliance behavior of the first-time entrepreneur, when necessary tax knowledge is acquired in the area of tax regulations, accurate filing of tax returns, and paying complete tax returns on time (Nagel et al., 2019). The training increases the level of tax compliance, which will definitely increase tax revenue generation in the short run. This outcome further buttresses Yahaya (2015), employing that knowledge is power and key to tax compliance, owning that people would only cooperate and respond to information having full knowledge of the benefit or demerit thereof.

\section{CONCLUSION}

This study examined the influence of tax fairness and tax knowledge on tax compliance behavior of listed manufacturing companies in both consumer goods and industrial goods sectors of the Nigerian economy.

This study found that tax fairness is significant but negative influence, which indicates that tax fairness is essential in tax compliance decisions. From the data collected and analyzed, it implies that government did not distribute the tax burden equitably and did not implement tax policies relative to the interests of all citizens in the country. The findings reveal that tax justice perception affects tax compliance behavior. Hence, this finding is an extension of the Laffer Curve Theory, which advocates for optimal tax payment at the point where both the government and taxpayers are at par in terms of tax revenue and tax payment.

Furthermore, the empirical result is in line with the Laffer Curve Theory argument on the need to sensitize the general populace to be tax compliant. Therefore, considering the level of education of corporate taxpayers in this study, tax knowledge significantly influenced tax compliance behavior. The findings revealed the empirical evidence that tax preparation, the efficiency of tax services, tax planning, tax literacy, and expectations of justice in the tax system affect corporate tax compliance. Tax policy should be designed to reduce tax evasion and promote fairness in taxation.

Therefore, government and policymakers should put into consideration taxpayers' opinions and contributions when reviewing new tax policy reforms in the country. Data-driven decision-making, through the identification of non-taxpayers, collects money from compliant taxpayers, which will accelerate tax recovery, collective and revenue generation performance in the country.

\section{AUTHOR CONTRIBUTIONS}

Conceptualization: Tony Nwanji, Bitrus Godo, Adekunle Adegboyegun.

Data curation: Bitrus Godo, Adekunle Adegboyegun.

Funding acquisition: Olufemi Oladipo.

Investigation: Damilola Eluyela, Adekunle Adegboyegun.

Methodology: Olufemi Oladipo, Damilola Eluyela.

Project administration: Tony Nwanji.

Resources: Bitrus Godo.

Software: Damilola Eluyela. 
Supervision: Olufemi Oladipo.

Validation: Olufemi Oladipo, Tony Nwanji, Adekunle Adegboyegun.

Visualization: Damilola Eluyela, Bitrus Godo.

Writing - original draft: Olufemi Oladipo.

Writing - review \& editing: Tony Nwanji.

\section{REFERENCES}

1. Afuberoh, D., \& Okoye, E. (2014). The impact of taxation on revenue generation in Nigeria: A study of Federal Capital Territory and selected states. International Journal of Public Administration and Management Research (IJPAMR), 2(2), 22-47.

2. Akintoye, I. R., \& Tashie, G. A. (2013). The effect of tax compliance on economic growth and development in Nigeria, West-Africa. British Journal of Arts and Social Sciences, 11(11), 222-231. Retrieved from http:// www.bjournal.co.uk/paper/ BJASS_11_2/BJASS_11_02_08.pdf

3. Bayer, R., \& Cowell, F. (2016). Tax Compliance by Firms and Audit Policy. Research in Economics, 70(1), 38-52. https://doi. org/10.1016/j.rie.2015.07.003

4. Bernard, O. M., Memba, F. S., \& Oluoch, O. (2018). Influence of tax knowledge and awareness on tax compliance among investors in the export processing zones in Kenya. International Journal of Scientific Research and Management, 6(10), 728-733. https://doi.org/10.18535/ijsrm/ v6i10.em01

5. Bobek, D. D., \& Hatfield, R. C. (2003). An investigation of the theory of planned behavior and the role of moral obligation in tax compliance. Behavioral Research in Accounting, 15(1), 13-38. https://doi.org/10.2308/ bria.2003.15.1.13

6. Doran, M. (2009). Tax Penalties and Tax Compliance. Georgetown University Law Center. Retrieved from https://scholarship.law. georgetown.edu/cgi/viewcontent. cgi article $=1918 \&$ context $=$ facpub

7. Faizal, S. M., \& Palil, M. R. (2015) Study on fairness and individual tax compliance in Malaysia: preliminary findings. International Journal of Business, Economics and Law, 8(1), 74-79. Retrieved from http://ijbel.com/wp-content/uploads/2016/01/Acc-35.pdf

8. Faizal, S. M., Palil, M. R., Maelah, R., \& Ramli, R. (2017). Perception on justice, trust and tax compliance behavior in Malaysia. Kasetsart Journal of Social Sciences, 38(3), 226-232. https://doi. org/10.1016/j.kjss.2016.10.003

9. Falade, O. E., \& Olagbaju, I. O. (2015). Effect of government capital expenditure on manufacturing sector output in Nigeria. Business and Economic Research, 5(2), 136-152. Retrieved from https://ideas.repec.org/a/ mth/ber888/v5y2015i2p136-152. html

10. FIRS. (2018). Understanding Tax and its effects on Nigerian businesses. Proceedings of the tax conference organized by the National Chamber of Commerce, Industry, Mines and Agriculture (NACCIMA) with LIRS and FIRS Lagos.

11. Gberegbe, F. B., Gabriel, A., \& Nkanbia-Davies, L. O. (2015). Perception of Tax Fairness and Personal Income Tax Compliance in Ken Saro-Wiwa Polytechnic, Bori. IOSR Journal of Economics and Finance, 6(6), 1-11. Retrieved from https://www.iosrjournals. org/iosr-jef/papers/Vol6-Issue6/ Version-1/A06610111.pdf

12. Guzel, S. A., Ozer, G., \& Ozcan, M (2019). The effect of the variables of tax justice perception and trust in government on tax compliance: The case of Turkey. Journal of Behavioral and Experimental Economics, 78, 80-86. https://doi. org/10.1016/j.socec.2018.12.006

13. Jurney, S., Rupet, T., \& Wartick, M. (2017). Generational differences in perceptions of tax fairness and attitudes towards compliance. In J. Hasseldine (Ed.), Advances in Taxation, 24 (pp. 163-197). Emerald Publishing Limited.

14. Khasawneh, A., Ibrahim Obeidat, M., \& Abdullah AlMomani, M. (2008). Income Tax Fairness and the Taxpayers' Compliance in Jordan. Journal of Economics and Administrative Sciences, 24(1), 15-39. https://doi. org/10.1108/10264116200800002

15. Kirchler, E. (2007). The economic psychology of tax behaviour. Cambridge: Cambridge University Press.

16. Lipatov, V. (2012). Corporate tax evasion: The case for specialists. Journal of Economic Behavior \& Organization, 81(1), 185206. https://doi.org/10.1016/j. jebo.2011.09.015

17. Marion, J., \& Muehlegger, E. (2018). Tax compliance and fiscal externalities: Evidence from U.S diesel taxation. Journal of Public Economics, 160, 1-13. https://doi. org/10.1016/j.jpubeco.2018.02.007

18. Nagel, H., Rosendahl, L., van Praag, M., \& Goslinga, S. (2019). The effect of a tax training program on tax compliance and business outcomes of starting entrepreneurs: Evidence from a field experiment. Journal of Business Venturing, 34(2), 261-283. https://doi.org/10.1016/j.jbusvent.2018.10.006

19. Newman, W., Charity, M., \& Ongayi, W. (2019). Literature Review on the Impact of Tax Knowledge on Tax Compliance among Small Medium Enterprises in a Developing Country. International Journal of Entrepreneurship, 22(4), 1-8. Retrieved from https://www. abacademies.org/abstract/litera- 
ture-review-on-the-impact-of-taxknowledge-on-tax-complianceamong-small-medium-enterprises-in-a-developing-countr-7571. html

20. Nigerian Stock Exchange. (2018). The Nigerian Stock Exchange Q3 fact sheet. Retrieved from https:// ngxgroup.com/exchange/data/ ngx-fact-sheet

21. Oladipo, O. A., Iyoha, F. O., Fakile, A. S., Asaleye, A. J., \& Eluyela, D. F. (2019). Do government taxes have implications on manufacturing sector output? Evidence from Nigeria. Journal of Management Information and Decision Sciences, 22(3), 181-190. Retrieved from http://eprints.lmu.edu.ng/2308/

22. Oladipupo, A. O., \& Obazee, U. (2016). Tax Knowledge, Penalties and Tax Compliance in Small and Medium Scale Enterprises in Nigeria. iBusiness, 8(1), 1-9. http:// dx.doi.org/10.4236/ib.2016.81001

23. Olaoye, C. O., Ayeni-agbaje, A. R., \& Alaran-ajewole, A. P. (2017). Tax Information, Administration and Knowledge on Tax Payers' Compliance of Block Moulding
Firms in Ekiti State. Journal of Finance and Accounting, 5(4), 131138. https://doi.org/10.11648/j. jfa.20170504.12

24. Oluyombo, O. O., \& Olayinka, O. M. (2018). Tax compliance and government revenue growth in Nigeria. Lapai International Journal of Administration, 1(2), 245-253. Retrieved from https:// www.academia.edu/37834668/ TAX_COMPLIANCE_AND_ GOVERNMENT_REVENUE_ GROWTH_IN_NIGERIA

25. Pratama, A. (2018). Individual Taxpayer Characteristics and Taxpayer Knowledge : Exploratory Survey on Individual Taxpayers in Bandung City, Indonesia. Review of Integrative Business and Economics Research, 7(1_ suppl), 338-349. Retrieved from http://buscompress.com/uploads/3/4/9/8/34980536/riber_7s1_sp_th17-090_338-349.pdf

26. Saad, N. (2014). Tax Knowledge, Tax Complexity and Tax Compliance: Taxpayers' View. Procedia - Social and Behavioral Sciences, 109, 1069-1075. https://doi.org/10.1016/j.sbspro.2013.12.590

27. Sausgruber, R., \& Tyran, J. (2014). Discriminatory taxes are unpopular - Even when they are efficient and distributionally fair. Journal of Economic Behavior \& Organization, 108, 463476. https://doi.org/10.1016/j. jebo.2013.12.022

28. Wrede, M. (2014). Fair inheritance taxation in the presence of tax planning. Journal of Behavioral and Experimental Economics, 51, 12-18. https://doi.org/10.1016/j. socec.2014.03.007.

29. Yahaya, L. (2015). The perception of corporate taxpayers' compliance behaviour under the self-assessment system in Nigeria. Journal of Management Research, 7(2), 343-352. https:// doi.org/10.5296/jmr.v7i2.6959

30. Zandi, G. (2016). Tax compliance audit: the perspectives of tax auditors in Malaysia. Asian Development Policy Review, 4(4), 143-149. https:// doi.org/10.18488/journal.107/2016.4.4/107.4.143.149

\section{APPENDIX A. Research questionnaire}

\section{Table A1. Tax fairness}

Please tick $\{\mathrm{V}\}$ correctly inside the box that perfectly suits your option.

\begin{tabular}{|c|c|c|c|c|c|c|}
\hline $\mathrm{S} / \mathrm{N}$ & TAX FAIRNESS & SA & A & U & D & SD \\
\hline TAF 1 & Tax burden among taxpayers is fairly distributed. & & & & & \\
\hline TAF 2 & Government implements tax policies fairly to the interests of all citizens in the country. & & & & & \\
\hline TAF 3 & The tax system and tax rate for the average taxpayer are fair in relation to the economy. & & & & & \\
\hline TAF 4 & Taxes are so heavy that tax evasion is an economic necessity for many companies to survive. & & & & & \\
\hline TAF 5 & Cheating on taxes is justifiable in light of the unfairness of the tax system. & & & & & \\
\hline TAF 6 & Taxpayer's perception of fairness has an impact on the willingness to pay taxes. & & & & & \\
\hline
\end{tabular}

Note: SA - strongly agree, A - agree, U - undecided, D - disagree, SD - strongly disagree.

\section{Table A2. Tax knowledge}

Please Tick $\{\mathrm{V}\}$ correctly inside the box that perfectly suits your option.

\begin{tabular}{|c|c|c|c|c|c|c|}
\hline $\mathrm{S} / \mathrm{N}$ & TAX COMPLEXITY AND TAX KNOWLEDGE & SA & A & $\mathbf{U}$ & D & SD \\
\hline TCK 1 & Nigerian tax system and tax laws are too complex to understand by taxpayers. & & & & & \\
\hline TCK 2 & $\begin{array}{l}\text { The complexity of tax laws contributes to the "tax gap" that is what tax is owed and what is } \\
\text { paid. }\end{array}$ & & & & & \\
\hline TCK 3 & Our company used tax laws and tax consultants in a creative way to reduce tax liability. & & & & & \\
\hline TCK 4 & Tax avoidance does not violate the rules but goes against the spirit of the laws. & & & & & \\
\hline TCK 5 & The use of tax avoidance depends on the taxpayer's knowledge and information. & & & & & \\
\hline TCK 6 & Tax knowledge and tax preparer have a significant effect on taxpayers' compliance behavior. & & & & & \\
\hline
\end{tabular}

Note: SA - strongly agree, A - agree, U - undecided, D - disagree, SD - strongly disagree. 